\title{
Cover Device
}

National Cancer Institute

\section{Source}

National Cancer Institute. Cover Device. NCI Thesaurus. Code C49896.

An object designed to conceal, enclose, cap, or protect something. 